\title{
The psychological processes that culminate in audience loyalty to a South African soap opera
}

Jani de Kock and Claire Wagner

Jani de Kock is an independent research consultant and part-time lecturer in research theory at the University of Pretoria, South Africa. E-mail: Janidk@gmail.com. Claire Wagner is associate professor in psychology, University of Pretoria. E-mail: Claire.wagner@up.ac.za .

\section{Abstract}

A model for the psychological processes that culminate in positive viewing experiences and audience loyalty to a soap opera is presented. The research was based on a secondary analysis of a qualitative market research study conducted for the SABC on the soap opera Isidingo. The analysis was conducted within a hermeneutic phenomenological interpretive framework. The model illustrates how viewers use soap-world knowledge and real-world knowledge to interpret the characters and storylines of soap operas, and that the degree of enjoyment the viewer experiences from viewing is dependent on the quality of the mental models formed of these respective components. The role that transportation, realism, social influences and timeslot play in the engagement process is also defined.

Key words: hermeneutic phenomenology, lived reality, market research, media psychology, qualitative research, secondary analysis, soap opera

\section{INTRODUCTION}

To production companies, broadcasters, and channel and network owners, media psychology is only of value if it can increase the likelihood that viewers will continue to watch their programmes. If media psychology can illustrate a clear pathway to repeated viewership, it can act as an indicator of consumption and potential profit. This study plots the psychological processes which contribute to pleasant viewing experiences and loyal viewership to a soap opera in the South African context. 


\section{THE RESEARCH AIM AND QUESTIONS}

The research is concerned with the process by which soap operas establish a continued interaction with their viewers. The justification for this research topic is primarily the inability of existing research on soap operas to address the issue. Much of what has been written on the genre has been descriptive of its effects on viewers (Ex, Janssens and Korzilius 2002; Haferkamp 1999; Larson 1996; Marx 2008; O'Guinn and Shrum 1997; Segrin and Nabi 2002; Wyer and Adaval 2004), the structural elements of a soap opera (Chamove and Mullins 1992; Pitout 1998), the interpretive soap opera viewer (Livingstone 1989, 1990, 1998), the diversification of the soap opera genre (Liebes and Livingstone 1998), multiculturalism in the South African soap opera (Lockyear 2004) and viewer representation of soap opera characters (Livingstone 1989).

Many studies (Busselle and Bilandzic 2008; Cohen 2001; Green, Brock and Kaufman 2004; Hoorn and Konijn 2003; Konijn and Hoorn 2005) have attempted to describe the process of engagement with and appeal of other television genres. These theories on viewership are helpful in understanding how viewers perceive, understand and engage with television characters (Busselle and Bilandzic 2008; Cohen 2001; Hoorn and Konijn 2003; Konijn and Hoorn 2005), and how the process of transportation into the narrative contributes to enjoyment (Busselle and Bilandzic 2008; Cohen 2001; Green et al. 2004).

Apart from Pitout (1998), few of these studies address the question of loyalty or the viewer's tendency to return to the programme episode after episode. Indeed, few have made any explicit attempt to explore the psychological processes by which programmes are able to sustain a relationship with their viewers. Since the reason behind the soap opera's ability to create unprecedented loyalty remains largely undiscovered in local academic literature, the research aim is to identify the psychological processes that culminate in positive viewing experiences and subsequent loyalty. The research question that arises for this study is: Can psychological processes that culminate in positive viewing experiences and audience loyalty to soap operas be identified? 


\section{LITERATURE REVIEW}

Busselle and Bilandzic's (2008) work represents the most contemporary theory that includes all combined elements recognised by the body of knowledge (media theory) on viewer engagement to date. For this study to add to the academic body of knowledge, it will have to acknowledge and either contribute to or invalidate their model as it pertains to the South African context. For this reason, their model is used as a general structure within which to understand other theories on media enjoyment. Their theory of narrative comprehension and engagement consists of three phases: comprehension, engagement and outcomes. Figure 1 is a visual representation of the model. Busselle and Bilandzic use a mental model approach to explain how the viewer interprets a television programme. A mental model is a cognitive structure that represents part of the external world, be it a process, typical behaviour in a given situation, a type of person, or any other slice of reality that the individual encounters in life.

The viewer's comprehension or interpretation of the soap opera consists of models that he/she builds around the story, characters and situation (i.e. setting of the story). Busselle and Bilandzic's (2008) model of narrative comprehension and engagement makes this same distinction and uses a mental models approach to explain how the process of forming a mental representation of the narrative is a necessary step towards viewer engagement. Their main argument is that reality judgements influence and potentially enhance or inhibit viewer engagement with the story.

The model incorporates the viewer's use of real-world knowledge and genre, the viewer's interpretation of characters, storyline and setting, as well as the concepts of realism, transportation and enjoyment, and proposes an integrated understanding of the lived reality. Figure 1 also indicates how some of the media theories mentioned earlier fit into Busselle and Bilandzic's (2008) model. 


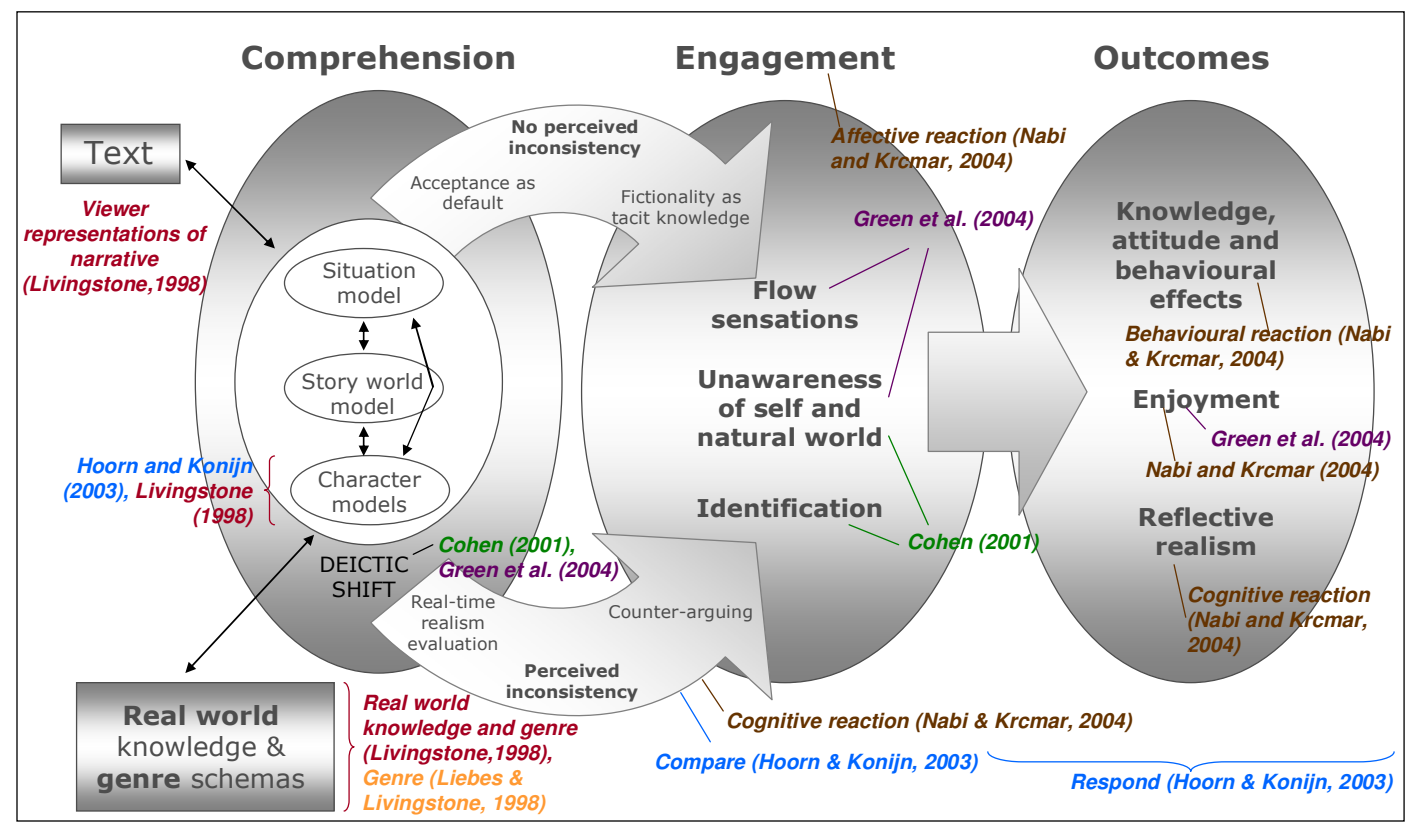

Figure 1: Fit between theories and Busselle and Bilandzic's (2008) model of narrative comprehension and engagement

Figure 1 shows that Livingstone's (1998) discussion on narrative interpretation, which includes selective remembering of the narrative structure and characters involved in storylines, is useful in understanding how the text influences the creation of the situation model (the primary mental model which acts as the mechanism through which the rest of the story is interpreted) and its underlying story-world and character models. Her analysis of character representations in Dallas, EastEnders and Coronation Street (Livingstone 1998), combined with Hoorn and Konijn's (2003) and Konijn and Hoorn's (2005) encoding phase, further explains the character models that viewers form. Real-world knowledge and genre schemas are resources that the viewer uses to fill in gaps that are present in the story (Busselle and Bilandzic, 2008; Livingstone, 1998). Liebes and Livingstone's (1998) diversification of the genre also informs the role of genre schemas in the formation of the situation model.

The deictic shift (experientially placing oneself inside the story) and the unawareness of self and the natural world show parallels with Cohen (2001) and Green et al. (2004), while the flow sensation (the experience when making the deictic shift) and identification (seeing yourself as one of the characters) are supported by Cohen (2001) and Green et al. (2004) respectively. Hoorn and Konijn's (2003) and Konijn and Hoorn's (2005) compare phase (in 
which the story is judged on similarity, relevance and valence) resonates with Busselle and Bilandzic's (2008) real-time realism evaluation (where the viewer compares mental models with pre-existing information and judges the story in terms of its relevance and realism), as well as with Nabi and Krcmar's (2004) cognitive enjoyment (in which the viewer comes to conscious conclusions about the story). The outcomes phase in Figure 1 (where the result and effect of viewing are summarised) also corresponds with Hoorn and Konijn's (2003) and Konijn and Hoorn's (2005) respond phase (where the balance between involvement and distance results in high or low appreciation) and the behavioural enjoyment (intent to watch again) of Nabi and Krcmar (2004). Enjoyment as a whole, which fits into the outcomes phase above, is discussed at length by Green et al. (2004) and Nabi and Krcmar (2004).

The term 'parasocial interaction' was coined by Horton and Wohl in the 1950s. It describes the viewer's tendency to imagine interacting with characters on the programme as if they were real people. Contrasted to the individual nature of identification, parasocial interaction assumes at least a degree of distance from the text, as well as a measure of self-awareness for the viewer. Where identification would see the viewer experience the story akin to being the character, parasocial interaction assumes a relationship with the character. Parasocial relationships are rooted in interpersonal communication and are related to how friendships are formed (Cohen 1999, 2001 and 2004; Eyal and Rubin 2003; Giles 2002).

\section{RESEARCH METHODOLOGY}

\section{Secondary analysis of data}

The research to establish a model of the psychological processes that culminate in audience loyalty to a South African soap opera was conducted through a secondary analysis of existing market data. Isidingo is a soap opera on South African television, broadcast (at the time of the research) on SABC3 at 18:30 every week-night. It is set in and around Johannesburg, in contemporary time. When first introduced to South African audiences, the soap's main setting was Horizon Deep, a mining community just outside of Johannesburg. At the time of the research, the mining business had been replaced by the television station ON!TV as the main setting but many characters still had ties to The Deep as the mine was colloquially referred to. 
This market research study (Conducted by QI, 2006) comprised a comprehensive evaluation of Isidingo, with the purpose of making strategic recommendations aimed at having the desired effect of retaining and growing an audience for the soap opera.

The data from the market research study included ten focus groups, five diaries of loyal soap opera viewers who were asked not to watch Isidingo for a week and keep a record of their experience, a focus group conducted with these viewers after the completion of the deprivation exercise, the Market Research Company's field notes, the market research report and the academic researcher's own reflective diary.

The academic study was therefore a secondary analysis of two sets of interpretations - those of the soap opera viewer (i.e. the research participants) and that of the Market Research Company. The Market Research Company read the transcripts representing the interpretations of the soap opera viewers and, using other background knowledge (including her own understanding of the lived reality of soap opera viewership, experience in other audience research, and an understanding of the objective of the $S A B C$ ), interpreted their interpretations.

\section{Hermeneutic phenomenology}

The study was conducted from within a hermeneutic phenomenological tradition. Using key principles of hermeneutic phenomenology, such as the hermeneutic spiral (that interpretations build on one another) and foregrounding of knowledge (that no interpretation is made independent of existing knowledge on a lived reality) (Conroy 2003; Laverty 2003), the academic researcher re-analysed the market research study to arrive at an understanding of the psychological processes that culminate in positive viewing experiences and loyalty to a soap opera. This resulted in three hermeneutics (interpretations):

- The first hermeneutic: the interpretations made by the soap opera viewers who participated in the market research study;

- The second hermeneutic: the interpretations made by the company who conducted the market research study; 
- The third hermeneutic: the interpretations made by the academic researcher.

The first analysis task was to identify meaning units that were of significance to the research question. Ratner (2001) argues that a meaning unit should be a coherent and distinct meaning extracted from the narrative being studied. To qualify as a meaning unit, it must conserve the psychological integrity of the theme being expressed, by neither reducing it to meaningless abbreviated segments nor confounding it by making references to other ideas.

After identifying and elaborating on meaning units, themes that recurred in the narrative and related to the research question were searched for. In this instance a theme is considered to be an interpretive conclusion that the participant ascribes to and allows to influence his/her behaviour. Techniques used to identify themes included looking for ideas that recurred with and across different accounts, looking for terms or expressions that were used in an unusual way by all members of the group, looking for metaphoric speech that left out information everyone knows (which is implied by what is said), comparing different groups' answers to the same question (similarities could lead to themes, while differences could be telling of subthemes within different demographics) and so forth.

The concluding task in establishing the hermeneutic interpretive framework entailed creating an extensive, integrated description of the lived experience from the individual level of expressions and meanings (Thompson 1997). Becoming immersed in the background of literature on the subject was most relevant at this stage. Interpretation at this point did not consist of extracting a theory from the data, nor of fitting an understanding derived from literature onto the text. Rather, the developing theoretical background became a frame of reference within which interpretation took place, while engagement with the participants' narratives allowed the opportunity for these initial (theoretical) interpretations to be changed and extended (Thompson 1997).

\section{ANALYSIS: COMPARING THE THEMES FROM THE THREE HERMENEUTICS}

Table 1 provides a comparison of the themes in the first and second hermeneutics with the literature review and the researcher's own conclusions from the third hermeneutic. Where 
relevant, the themes in Table 1 are incorporated into the models that will be discussed in the next section.

Table 1: Comparing the three hermeneutics

\begin{tabular}{|c|c|c|c|}
\hline The soap opera viewer & $\begin{array}{l}\text { Market Research } \\
\text { Company }\end{array}$ & Literature & Conclusion \\
\hline $\begin{array}{l}\text { Themes from the first } \\
\text { hermeneutic }\end{array}$ & $\begin{array}{l}\text { Themes } \\
\text { rephrased in the } \\
\text { second } \\
\text { hermeneutic }\end{array}$ & $\begin{array}{l}\text { Literature that } \\
\text { explicates the } \\
\text { theme }\end{array}$ & $\begin{array}{l}\text { Final themes } \\
\text { consolidation in the third } \\
\text { hermeneutic }\end{array}$ \\
\hline $\begin{array}{l}\text { Theme 1: The outcome of } \\
\text { viewers' interpretation of } \\
\text { their viewing experience is } \\
\text { regular viewing behaviour. }\end{array}$ & $\begin{array}{l}\text { Elaborated on in } \\
\text { the second } \\
\text { hermeneutic. }\end{array}$ & $\begin{array}{l}\text { Nabi and Krcmar } \\
\text { (2004) }\end{array}$ & $\begin{array}{l}\text { Conclusion 1: The } \\
\text { outcome of viewers' } \\
\text { interpretation of their } \\
\text { viewing experience is } \\
\text { regular viewing behaviour. }\end{array}$ \\
\hline $\begin{array}{l}\text { Theme 2: Motivation for } \\
\text { loyalty to soap operas is } \\
\text { primarily interpreted by the } \\
\text { viewer as an interest in } \\
\text { characters. }\end{array}$ & $\begin{array}{l}\text { Renamed to: } \\
\text { Theme } \\
\text { Motivation for } \\
\text { loyalty to soap } \\
\text { operas is primarily } \\
\text { interpreted by the } \\
\text { viewer as } \\
\text { involvement with } \\
\text { characters. }\end{array}$ & $\begin{array}{l}\text { Cohen (2001); } \\
\text { Hoorn and Konijn } \\
\text { (2003); Konijn and } \\
\text { Hoorn (2005); } \\
\text { Livingstone } \\
\text { (1998) }\end{array}$ & $\begin{array}{l}\text { Conclusion 2: Motivation } \\
\text { for loyalty to soap operas } \\
\text { is primarily interpreted by } \\
\text { the viewer as an } \\
\text { appreciation } \\
\text { characters. } \\
\text { Conclusion 2.1: Viewers } \\
\text { interpret characters using }\end{array}$ \\
\hline - & $\begin{array}{l}\text { Additional sub- } \\
\text { theme: } \\
\text { Representation as } \\
\text { agent of } \\
\text { identification. }\end{array}$ & Cohen (2001) & $\begin{array}{l}\text { two sets of resources, } \\
\text { namely soap-world } \\
\text { knowledge and real-world } \\
\text { knowledge. }\end{array}$ \\
\hline
\end{tabular}




\begin{tabular}{|c|c|c|c|}
\hline $\begin{array}{l}\text { Sub-theme: Loyalty to soap } \\
\text { operas is positively } \\
\text { influenced by viewers' } \\
\text { knowledge of the respective } \\
\text { characters. }\end{array}$ & $\begin{array}{l}\text { Elaborated on in } \\
\text { the second } \\
\text { hermeneutic. }\end{array}$ & $\begin{array}{l}\text { Livingstone } \\
\text { (1998) }\end{array}$ & $\begin{array}{l}\text { Conclusion 2.2: Viewers } \\
\text { form a complex schema of } \\
\text { who the character is and } \\
\text { this schema underlies the } \\
\text { expectation viewers have }\end{array}$ \\
\hline $\begin{array}{l}\text { Sub-theme: Loyalty to soap } \\
\text { operas is positively } \\
\text { influenced by viewers } \\
\text { forming para-social } \\
\text { relationships } \\
\text { characters. }\end{array}$ & $\begin{array}{l}\text { Elaborated on in } \\
\text { the second } \\
\text { hermeneutic. }\end{array}$ & Cohen (2001) & $\begin{array}{l}\text { of the character's future } \\
\text { behaviour and } \\
\text { interactions with other } \\
\text { characters. } \\
\text { Conclusion 2.3: Viewers }\end{array}$ \\
\hline $\begin{array}{l}\text { Sub-theme: There are two } \\
\text { types of characters, normal } \\
\text { and hate characters, and } \\
\text { viewers relate to these two } \\
\text { types of characters } \\
\text { differently. }\end{array}$ & $\begin{array}{l}\text { Renamed to: Sub- } \\
\text { theme: } \\
\text { Motivation for } \\
\text { loyalty to soap } \\
\text { operas is primarily } \\
\text { interpreted by the } \\
\text { viewer in terms of } \\
\text { an emotional } \\
\text { reaction to the } \\
\text { character. }\end{array}$ & $\begin{array}{l}\text { Cohen (2001); } \\
\text { Hoorn and Konijn } \\
\text { (2003); Konijn and } \\
\text { Hoorn (2005); } \\
\text { Livingstone, } \\
\text { (1998); Nabi and } \\
\text { Krcmar (2004) }\end{array}$ & $\begin{array}{l}\text { relate to characters in a } \\
\text { variety of ways, each of } \\
\text { which makes a unique } \\
\text { contribution to the overall } \\
\text { appeal of and loyalty to a } \\
\text { soap opera. }\end{array}$ \\
\hline $\begin{array}{l}\text { Theme 3: Loyalty to soap } \\
\text { operas is interpreted by } \\
\text { viewers as an interest in } \\
\text { storylines. }\end{array}$ & $\begin{array}{l}\text { Elaborated on in } \\
\text { the second } \\
\text { hermeneutic. }\end{array}$ & $\begin{array}{l}\text { Livingstone } \\
\text { (1998) }\end{array}$ & $\begin{array}{l}\text { Conclusion 3: Loyalty to } \\
\text { soap operas is interpreted } \\
\text { by viewers as an interest in } \\
\text { storylines. }\end{array}$ \\
\hline $\begin{array}{l}\text { Sub-theme: How will } \\
\text { characters react when they } \\
\text { find out what I already } \\
\text { know? }\end{array}$ & $\begin{array}{l}\text { Not present in the } \\
\text { second } \\
\text { hermeneutic. }\end{array}$ & Tulloch (2000) & $\begin{array}{l}\text { Conclusion 3.1: Viewers' } \\
\text { interpretations of } \\
\text { storylines are influenced }\end{array}$ \\
\hline
\end{tabular}




\begin{tabular}{|c|c|c|c|}
\hline $\begin{array}{l}\text { Sub-theme: Anticipation of } \\
\text { what will happen next. }\end{array}$ & $\begin{array}{l}\text { Elaborated on in } \\
\text { the second } \\
\text { hermeneutic. }\end{array}$ & $\begin{array}{l}\text { Livingstone } \\
\text { (1998) }\end{array}$ & $\begin{array}{l}\text { by their relationship with } \\
\text { characters. }\end{array}$ \\
\hline $\begin{array}{l}\text { Sub-theme: Types of } \\
\text { storylines preferred. }\end{array}$ & $\begin{array}{l}\text { Renamed to: Sub- } \\
\text { theme: Types of } \\
\text { storylines that } \\
\text { contribute more } \\
\text { to loyalty. }\end{array}$ & $\begin{array}{l}\text { Livingstone } \\
\text { (1998) }\end{array}$ & $\begin{array}{l}\text { Conclusion 3.2: Isidingo is } \\
\text { partly true to genre } \\
\text { conventions in the types } \\
\text { of storylines portrayed. }\end{array}$ \\
\hline $\begin{array}{l}\text { Theme } 4: \text { A preference for } \\
\text { all things real. }\end{array}$ & $\begin{array}{l}\text { Renamed to: } \\
\text { Theme 4: The } \\
\text { importance of } \\
\text { fantasy and } \\
\text { realism. }\end{array}$ & $\begin{array}{l}\text { Busselle and } \\
\text { Bilandzic (2008) }\end{array}$ & $\begin{array}{l}\text { Conclusion 4: Realism is an } \\
\text { important determinant of } \\
\text { viewers' judgement of } \\
\text { characters. }\end{array}$ \\
\hline $\begin{array}{l}\text { Sub-theme: International } \\
\text { soaps are more unrealistic } \\
\text { than local soaps. }\end{array}$ & $\begin{array}{l}\text { Elaborated on in } \\
\text { the second } \\
\text { hermeneutic. }\end{array}$ & $\begin{array}{l}\text { Busselle and } \\
\text { Bilandzic (2008). }\end{array}$ & $\begin{array}{l}\text { Conclusion 4.1: There are } \\
\text { different types of realism. } \\
\text { Isidingo's strength is }\end{array}$ \\
\hline $\begin{array}{l}\text { Theme 5: The specific } \\
\text { appeal of Isidingo is } \\
\text { interpreted by the viewer as } \\
\text { its ability to simulate reality. }\end{array}$ & $\begin{array}{l}\text { Elaborated on in } \\
\text { the second } \\
\text { hermeneutic. }\end{array}$ & $\begin{array}{l}\text { Busselle and } \\
\text { Bilandzic (2008) }\end{array}$ & $\begin{array}{l}\text { external realism, } \\
\text { combined with internal } \\
\text { realism. }\end{array}$ \\
\hline $\begin{array}{l}\text { Sub-theme: Isidingo's } \\
\text { characters are real. }\end{array}$ & $\begin{array}{l}\text { Renamed to: Sub- } \\
\text { theme: Most of } \\
\text { Isidingo's } \\
\text { characters are } \\
\text { real. }\end{array}$ & $\begin{array}{l}\text { Busselle and } \\
\text { Bilandzic (2008) }\end{array}$ & $\begin{array}{l}\text { Conclusion 4.2: External } \\
\text { realism is not a necessary } \\
\text { determinant of loyalty to } \\
\text { all soap operas. }\end{array}$ \\
\hline $\begin{array}{l}\text { Sub-theme: Isidingo's } \\
\text { storylines are real. }\end{array}$ & $\begin{array}{l}\text { Elaborated on in } \\
\text { the second } \\
\text { hermeneutic. }\end{array}$ & $\begin{array}{l}\text { Busselle and } \\
\text { Bilandzic (2008). }\end{array}$ & \\
\hline $\begin{array}{l}\text { Sub-theme: Isidingo is } \\
\text { educational. }\end{array}$ & $\begin{array}{l}\text { Elaborated on in } \\
\text { the second } \\
\text { hermeneutic. }\end{array}$ & $\begin{array}{l}\text { Ex et al. (2002); } \\
\text { O'Guinn } \\
\text { Shrum }\end{array}$ & $\begin{array}{l}\text { Conclusion 5: The effect of } \\
\text { loyal viewership of }\end{array}$ \\
\hline
\end{tabular}




\begin{tabular}{|c|c|c|c|}
\hline & & $\begin{array}{l}\text { Wyer and Adaval } \\
\text { (2004) }\end{array}$ & $\begin{array}{l}\text { Isidingo is education or } \\
\text { learning. } \\
\text { Conclusion 5.1: Isidingo } \\
\text { has the potential to shape } \\
\text { public opinion on key } \\
\text { social issues. }\end{array}$ \\
\hline $\begin{array}{l}\text { Theme 6: Loyalty to all soap } \\
\text { operas is also interpreted by } \\
\text { viewers as a function of the } \\
\text { timeslot in which soap } \\
\text { operas play. }\end{array}$ & $\begin{array}{l}\text { Elaborated on in } \\
\text { the second } \\
\text { hermeneutic. }\end{array}$ & $\begin{array}{l}\text { Tager (1997); } \\
\text { Warth (1994) }\end{array}$ & $\begin{array}{l}\text { Conclusion 6: The } \\
\text { temporal location of the } \\
\text { soap opera within the } \\
\text { household routine is a } \\
\text { determining factor as } \\
\text { regards loyalty. }\end{array}$ \\
\hline $\begin{array}{l}\text { Theme 7: Loyalty to soaps is } \\
\text { also interpreted as a } \\
\text { function of the social aspect } \\
\text { of viewership. }\end{array}$ & $\begin{array}{l}\text { Elaborated on in } \\
\text { the second } \\
\text { hermeneutic. }\end{array}$ & $\begin{array}{lr}\text { Giles } & \text { (2002); } \\
\text { Hobson } & \text { (1994); } \\
\text { Kreutzner } & \text { and } \\
\text { Warth } & (1994) ; \\
\text { Riegel } & (1996) ; \\
\text { Tager } & (1997) ; \\
\text { Tulloch (2000) }\end{array}$ & $\begin{array}{l}\text { Conclusion 7: Social } \\
\text { influence is an important } \\
\text { psychological process that } \\
\text { instigates and sustains } \\
\text { soap opera viewership. }\end{array}$ \\
\hline $\begin{array}{l}\text { Theme 8: The difference } \\
\text { between occasional and } \\
\text { regular viewers is mainly } \\
\text { viewing behaviour. }\end{array}$ & $\begin{array}{l}\text { Renamed to: } \\
\text { Theme 8: The } \\
\text { difference } \\
\text { between } \\
\text { occasional and } \\
\text { regular viewers is } \\
\text { mainly character } \\
\text { involvement. }\end{array}$ & Cohen (2001) & $\begin{array}{l}\text { Conclusion 8: Character } \\
\text { involvement is positively } \\
\text { influenced by a regular } \\
\text { exposure to the } \\
\text { characters. }\end{array}$ \\
\hline- & $\begin{array}{l}\text { Additional theme: } \\
\text { Theme 9: The } \\
\text { importance of the }\end{array}$ & $\begin{array}{l}\text { Busselle and } \\
\text { Bilandzic (2008) }\end{array}$ & $\begin{array}{l}\text { Conclusion 9: The spatial } \\
\text { setting of a soap forms } \\
\text { part of its situation model. }\end{array}$ \\
\hline
\end{tabular}




\begin{tabular}{|c|c|c|c|}
\hline & $\begin{array}{l}\text { setting of the } \\
\text { soap. }\end{array}$ & & \\
\hline - & $\begin{array}{l}\text { Additional theme: } \\
\text { Theme 10: The } \\
\text { appeal of the soap } \\
\text { genre in general. }\end{array}$ & $\begin{array}{l}\text { Livingstone } \\
\text { (1998) }\end{array}$ & $\begin{array}{l}\text { Conclusion 10: Isidingo } \\
\text { viewers find the genre in } \\
\text { general appealing. } \\
\text { Conclusion 10.1: Soap } \\
\text { opera viewers are familiar } \\
\text { with soap opera genre } \\
\text { conventions and these } \\
\text { influence } \\
\text { expectations of characters } \\
\text { and storylines. }\end{array}$ \\
\hline $\begin{array}{l}\text { Theme 11: Loyalty is } \\
\text { interpreted by viewers as an } \\
\text { appreciation of escapism. }\end{array}$ & $\begin{array}{l}\text { Elaborated on in } \\
\text { the second } \\
\text { hermeneutic. }\end{array}$ & $\begin{array}{l}\text { Green et al. } \\
(2004)\end{array}$ & $\begin{array}{l}\text { Conclusion 11: } \\
\text { Transportation is a } \\
\text { necessary determinant of } \\
\text { loyalty. }\end{array}$ \\
\hline
\end{tabular}

INTERPRETATION: TWO PROCESSES THAT CULMINATE IN POSITIVE VIEWING EXPERIENCES

Two distinct processes emerge from the above that culminate in positive viewing experiences: the process through which viewers come to enjoy narrative progressions in the soap opera, and that through which viewers experience enjoyment as a result of their engagement with soap opera characters.

Viewers use two sets of resources when interpreting a soap opera - real-world knowledge and soap-world knowledge (genre schemas). Both processes are based on the assumption (see Figure 2) that as a viewer is transformed from novice to occasional viewer to loyal viewer, his/her soap-world knowledge increases, with important implications for the viewer's enjoyment. 


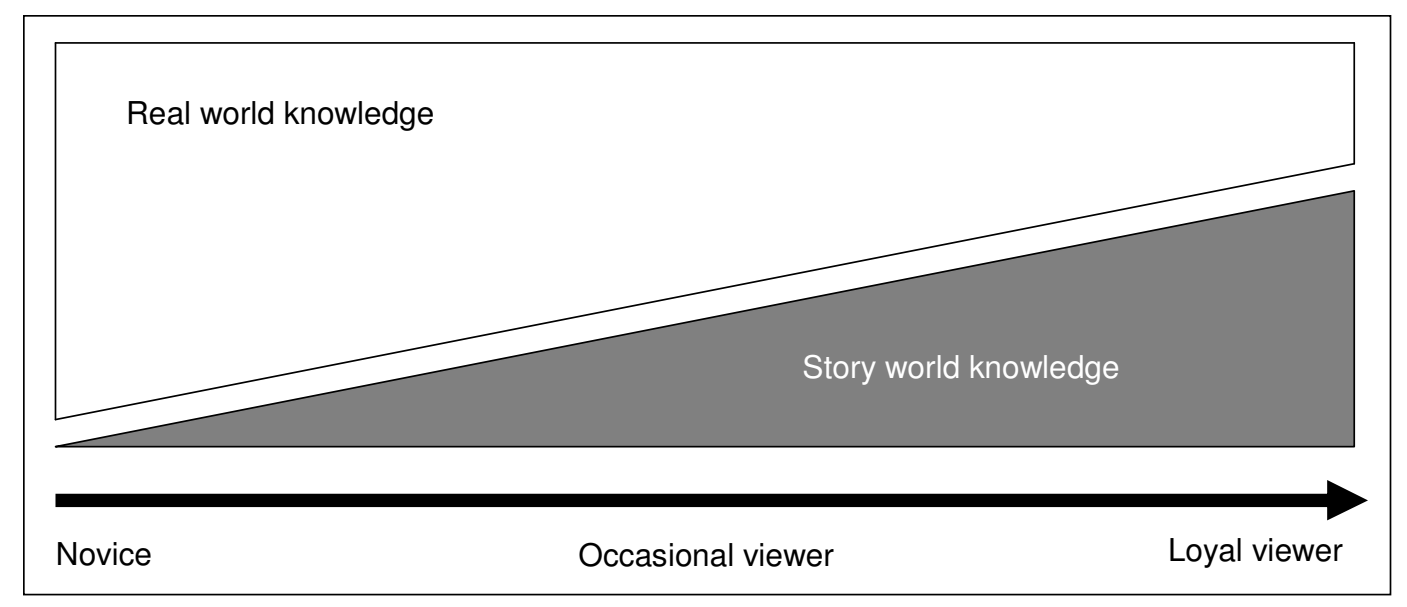

Figure 2: The transition from novice to loyal viewer

The first process that has important enjoyment benefits is that through which viewers experience enjoyment from interpreting the narrative. This model represents an application of Livingstone's (1998) theory to the first and second hermeneutic. Figure 3 depicts how viewers derive enjoyment from interpreting the narrative.

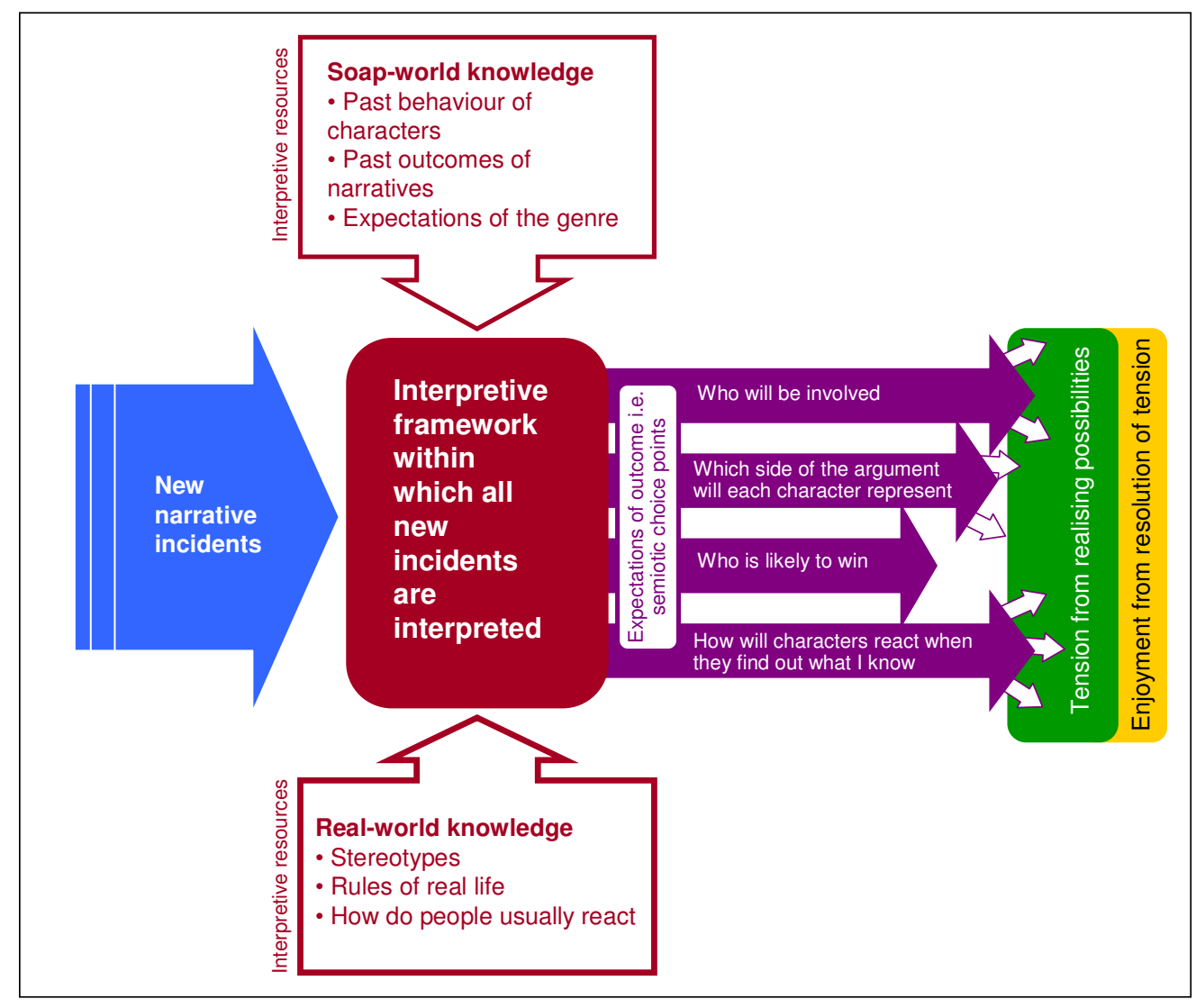

Figure 3: Enjoyment from interpreting the narrative 
The viewer develops an interpretive framework by means of the two sets of interpretive resources, namely real-world knowledge and soap-world knowledge. From this collective whole, the viewer has certain expectations of what could potentially happen at each semiotic choice point in the narrative. The semiotic choice point is a moment in the narrative at which new information is revealed and where the viewer, interpreting this new information from within the interpretive framework, generates a range of potential outcomes. These expectations might include anything from the specific characters who could be expected to be involved, to the potential outcome. The extent of the viewer's narrative insight (interpretive framework) determines the number of possible outcomes and implications he/she will be aware of. If the range is large, the viewer experiences a higher degree of tension prior to the outcome being made known. Enjoyment is experienced when this variable level of tension is resolved. The narrative insight (extent of narrative possibility the viewer is aware of) is directly correlated to the possible enjoyment he/she may derive from the narrative experience.

The second process through which the viewer experiences enjoyment from watching a soap opera, is engagement with characters. Figure 4 represents an integration of the models of Busselle and Bilandzic (2008), Cohen (2001), Green et al. (2004), Hoorn and Konijn (2003), Konijn and Hoorn (2005) and Livingstone (1998), as well as the first and second hermeneutic. 


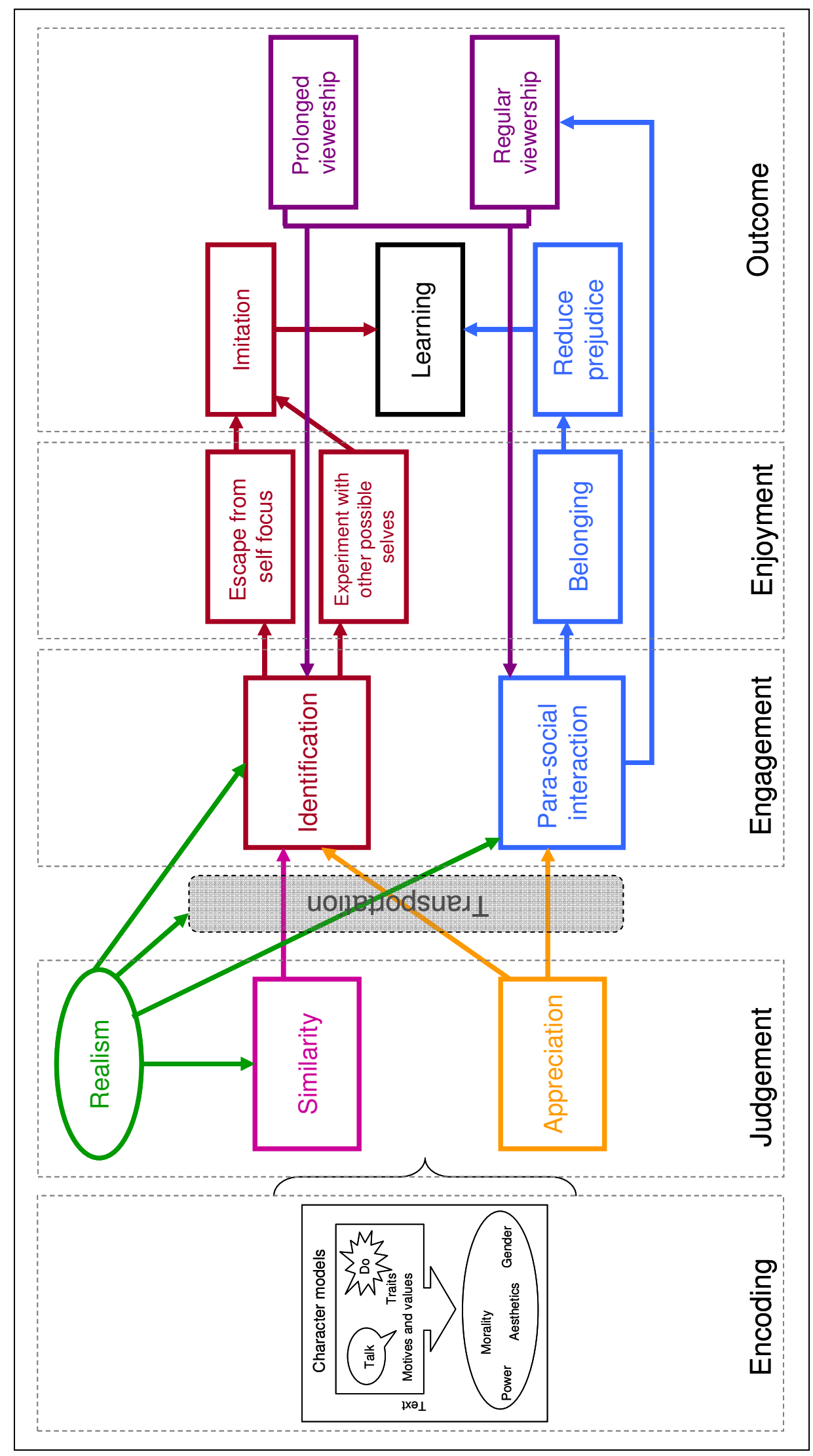

Figure 4: Enjoyment through engagement with characters 
Prior to establishing engagement with a character, the viewer forms mental models of the characters by interpreting fragmented pieces of information. Viewers deduce character traits from characters' behaviour in different contexts, and gain access to their motives and values through the discussions those characters have with others. During the encoding phase these traits are assembled into coherent mental models that consist of several dimensions (for example, gender, power, aesthetics and morality), each of which has either a positive or a negative pole. During the judgement phase, viewers measure the degree of similarity between themselves and the characters, and arrive at a level of appreciation for the character (where combinations of both positive and negative traits usually - but not exclusively - culminate in a high appreciation of respective characters). During this phase, the viewer also judges the realism of characters. Realism positively influences the viewer's ability to experience transportation, identification and para-social interactions, and increases the likelihood that the viewer may judge the character as being similar to themselves.

Viewers experience transportation and if a character is judged as similar to the viewer, he or she may identify with that character. Identification with a character leads to the enjoyable consequences of escaping self-focus and exploring alternative identities. With prolonged exposure this also leads to imitation, where identification extends outside of the soap opera into the real world. Although imitation could not be established in this study, through imitation - if with a positive character who exhibits positive traits or life skills - the viewer experiences learning and could potentially benefit from the viewing experience in real life. The possibility of identification is increased by prolonged exposure to the soap opera as well as through frequent exposure to the character.

When the viewer does not identify with a character but still has a high appreciation for him/her, the viewer potentially develops a para-social relationship with that character. The enjoyable benefit of para-social interaction is that the viewer gains a sense of belonging to a group. Since para-social interaction resembles real-life interaction, a positive outcome of this type of engagement is a reduction in prejudice and subsequent increase in learning. Para-social interaction is also positively 
influenced by prolonged and frequent exposure to a character. Interestingly, parasocial interaction is a motivation for viewing, and therefore increases the likelihood of continued viewership.

\section{CONCLUSION: A NEW MODEL}

Figure 5 represents a new model of the psychological processes that culminate in audience loyalty to a soap opera. The model illustrates how the interpretation of characters and narratives respectively contributes to positive viewing experiences. The enjoyment derived from interpreting characters and narratives is dependent on the quality of the mental models the viewer has of each of these aspects. The quality of mental models is dependent on the quality and quantity of viewership, which is a function of loyal viewing behaviour. Each of these aspects will be discussed in detail below.

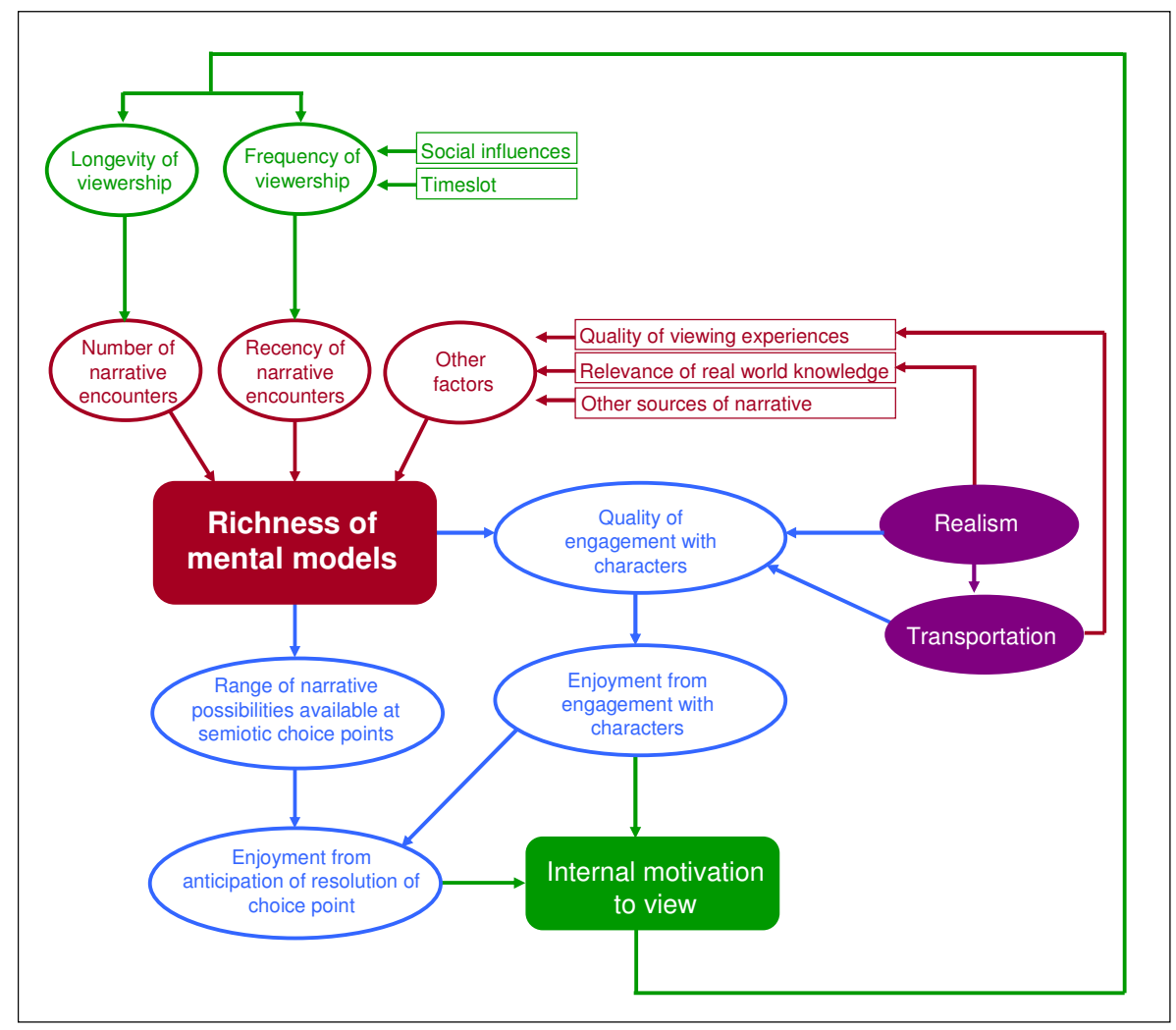

Figure 5: A new model - the psychological processes culminating in positive viewing experiences and audience loyalty to a soap opera 


\section{Quality of the mental models}

The viewer forms mental models that represent the soap opera by interpreting fragments of information obtained from watching the show. The richness of these mental models is primarily dependent on two factors, namely the frequency and the longevity of viewership. Longevity influences the total number of episodes watched (and therefore the total number of narrative incidents the viewer is exposed to), while frequency determines the recency and relevance of the narrative incidents the viewer is exposed to. The larger the number of narrative encounters and the more recent these encounters, the richer the mental models will be. Recency is important for ensuring that the viewer's mental model of both the characters and story-world logic is current to the narrative incidents at the time of viewership. A history of watching a large number of episodes with an interruption in viewership, although more valuable than no history of viewership is less valuable than a recent history of viewership, because of its applicability to current happenings. The quantity/number of episodes watched is an important determinant of quality, as it implies that the viewer will have had more unique, fragmented incidents to interpret. An impression formed of a character based on his/her behaviour in one incident will be less comprehensive (i.e. will encapsulate less of his/her total character) than an impression formed based on his/her behaviour in several incidents.

The richness of mental models is also determined by several other factors. It is first and foremost determined by the relevance of the real-world knowledge of the viewer to the interpretation of the narrative, which is dependent on its realism. If a soap opera has a high degree of external realism (for example, congruence between the way people behave on the show and the way real people do), any resources the viewer has for interpreting the real world is directly applicable to his/her interpretation of the soap opera. This may then counteract the lack of frequency and recency in exposure to the narrative, to some extent.

Another factor that influences the richness of the mental models formed is the quality of the viewing experience. If the viewing of an episode is not complete (i.e. the viewer 
does not watch the entire episode, as is the case with occasional viewers who migrate to competing soap operas during the same time-slot), the viewer is not exposed to all the incidents in the episode and does not exhaust the interpretive potential of the viewing experience. The quality of the viewing experience is also influenced by the degree to which transportation is able to take place. If transportation is interrupted by factors external (i.e. the telephone rings) or internal (perhaps a lack of internal realism that triggers viewer reflection and makes him/her aware of the self and the soap opera), the episode is watched primarily from a deictic position outside of the soap rather than from within, which subsequently hinders engagement with the characters.

The richness of mental models is lastly influenced by the viewer's access to other sources of interpretation of the soap opera. The primary source of information from which to form mental models is viewership itself, but this can be supplemented by, most notably, discussions with other viewers. Other sources may include soap opera magazines or online viewer forums, where other viewers discuss the soap opera (which the viewer can choose to participate in or read as an outsider).

\section{Enjoyment}

Rich mental models result in enjoyment for the viewer through two avenues: the progression of the narrative and engagement with characters. Every incident in a soap opera represents a semiotic choice point with different possible outcomes. The viewer who has a rich mental model of the soap opera recognises a large array of narrative possibilities (a cognitive dimension to enjoyment). The range and the extent of the implications that the viewer is aware of determine the tension he/she will experience in anticipation of a resolution of the semiotic choice point (an affective dimension of enjoyment). If the range and extent of the narrative possibilities the viewer is aware of are vast, he/she will experience a high degree of tension and subsequent enjoyment from the resolution of the narrative incident. This enjoyment will, in turn, make a contribution to the viewer's intrinsic motivation to watch another episode (a behavioural reaction to enjoyment). 
Rich mental models also determine the potential quality of the engagement the viewer could have with characters. When the viewer first watches a soap opera, he/she meets the characters in a way which is comparable to meeting people in real life. At this early stage of the engagement, the viewer relies on stereotypes to interpret any new characters and is limited to whatever small amount of information has been presented by the limited number of narrative encounters (the cognitive dimension of enjoyment). Given this limited information, the viewer is less able to judge and engage with the character than a viewer who has been exposed to a large number of narrative incidents. If the viewer is unable to judge the appeal and similarity of a character, he/she will not be able to identify with a character or to form parasocial relationships with characters which, in turn, negatively affects enjoyment. The viewer derives specific gratification from either identifying with a character or having para-social interaction with a character (affective dimension of enjoyment), which makes a contribution to the intrinsic motivation to continue watching on a regular basis (behavioural dimension of enjoyment).

Viewers selectively recall only those elements of a storyline that relate to the characters they have a high appreciation for. The nature of the viewer's engagement with characters therefore also influences the range of narrative possibilities the viewer is aware of at semiotic choice points.

Realism is another important determinant of the quality of the viewer's engagement with characters. Realism positively influences transportation, which is a necessary condition for engaging with characters and it also influences engagement with characters directly, as it is easier for the viewer to identify with or have para-social interactions with realistic characters.

\section{Loyalty}

The enjoyment derived from engaging with characters and from anticipating the resolution of storylines combines into an internal motivation to watch another episode. This internal motivation is supplemented by social influence, which encourages the viewer to watch an episode together with significant others. Such 
motivation is also positively influenced by the convenience of the time-slot in which the soap opera airs. Watching more episodes (i.e. becoming a more regular viewer) repeats this process and results in richer mental models, greater enjoyment and increased internal motivation to watch.

If a soap opera has a high degree of external realism (as is the case with Isidingo), an occasional viewer who has viewed fewer episodes in total and has had less recent exposure to the show, may be able to follow and anticipate much of what transpires because his/her real-world knowledge (i.e. bias) is applicable to the interpretation of the soap opera. The occasional viewer will, however, be limited to the real world as heuristic and will not be privy to idiosyncratic character and narrative histories, which will limit the range of narrative possibilities available at semiotic choice points and his/her subsequent enjoyment in anticipating narrative resolutions. Without frequent and lengthy exposure (and a fusion of horizons, in which the occasional viewer's bias and knowledge on the soap opera are broadened), the occasional viewer will not be able to sustain identification with any particular character or para-social relationships with a range of characters, which therefore limits his/her enjoyment gained from engagement with characters. If the total enjoyment derived from the viewing experience is low, the inherent motivation to continue watching will consequently be low. This lack of inherent motivation may, however, be supplemented by other factors that constitute the total facticity (the inseparability of our own being with that of others) and historicity (the temporal location of the viewing experience and the interpretations that preceded it), such as the time-slot in which the soap opera is aired or social pressure from spouses for the occasional viewer to watch. As the frequency and longevity of the occasional viewer's exposure to the soap increases over time, so does the richness of the mental models formed and the possible enjoyment that can be derived from viewing. In this cyclical manner, a lived reality of loyal viewership is formed.

Repeat viewership and loyalty are dependent on the richness of the mental models the viewer has at his/her disposal when interpreting characters and storylines. The most useful element available to the producers of soap operas is, therefore, the use 
of external realism. External realism increases the likelihood that the viewer's realworld knowledge will be relevant to his/her interpretation of the soap opera, which makes it easier for him/her to derive enjoyment from both the characters and the storylines. Using characters, stories and settings that remind them of their own lives will allow even novice viewers to engage with the narrative and should put the cyclical process, through which richer mental models are formed, into motion.

\section{FUTURE RESEARCH}

This analysis of Isidingo was limited to the storylines and characters immediately relevant to the soap prior to the collection of the first hermeneutic. Although this allowed the researcher to conduct a time-delimited analysis, it goes against the conventions of the soap genre, which has no definitive end. It also limited the soap's inherently complex multiplicity of characters to only a relatively small cast. Ideally, any analysis of a soap opera should acknowledge the role that the extended character ensemble and lack of narrative conclusion has on viewers' experience of the genre.

The current model is only applicable to narrative genres, because it requires the viewer to form relationships with characters and to be transported into the narrative. Although viewers can form relationships with media figures in non-narrative genres (it is, for instance, easier to engage para-socially with a media figure, such as a talk show host or a newscaster who addresses the audience directly), they are not likely to be transported into non-narrative genres, seeing that transportation requires an alternative narrative world (Cohen 2001; Green et al. 2004). A suggestion for future research would be to explore the possibilities of understanding viewer loyalty to nonnarrative genres, through an amended version of the model of psychological processes culminating in positive viewing experiences and audience loyalty.

The application of the model of the psychological processes culminating in positive viewing experiences and audience loyalty to the new media environment should be explored. Developments in media, such as view-on-demand content, PVRs, DVB-H technology (live television on a cell phone or other mobile device) and, most 
importantly, the Internet, hold vast implications for the lived reality of viewership. It also has implications for the repositioning of traditional views on how audiences should be understood and studied (Livingstone 1999). The model of psychological processes culminating in positive viewing experiences and audience loyalty should be adapted to the unique characteristics of the new media environment.

\section{REFERENCES}

Busselle, R. and H. Bilandzic. 2008. Fictionality and perceived realism in experiencing stories: A model of narrative comprehension and engagement. Communication Theory 18: 255-280.

Chamove, A.S. and P. Mullins. 1992. Communication in television soaps. New-Zealand Journal of Psychology 21(2): 67-70.

Cohen, J. 1999. Favorite characters of teenage viewers of Israeli serials. Journal of Broadcasting \& Electronic Media 43: 1-15.

Cohen, J. 2001. Defining identification: A theoretical look at the identification of audiences with media characters. Mass Communication and Society 4(3): 245264.

Cohen, J. 2004. Parasocial break-up from favorite television characters: The role of attachment styles and relationship intensity. Journal of Social and Personal Relationships 21(2): 187-202.

Conroy, S.A. 2003. A pathway for interpretive phenomenology. International Journal of Qualitative Methods 2(3): 1-43.

Ex, C., J. Janssens and H. Korzilius. 2002. Young females' images of motherhood in relation to television viewing. Journal of Communication 52(4): 955-971.

Eyal, K. and A.M. Rubin. 2003. Viewer aggression and homophily, identification, and parasocial relationships with television characters. Journal of Broadcasting \& Electronic Media 47: 77-98.

Giles, D.C. 2002. Parasocial interaction: A review of the literature and a model for future research. Media Psychology 4(3): 279-304. 
Green, M.C., T.C. Brock, and G.F. Kaufman. 2004. Understanding media enjoyment: The role of transportation into narrative worlds. Communication Theory 14(4): 311-327.

Haferkamp, C.J. 1999. Beliefs about relationships in relation to television viewing, soap opera viewing, and self-monitoring. Current Psychology: Developmental, Learning, Personality, Social 18(2): 193-204.

Hobson, D. 1994. Soap operas at work. In Remote control - television, audiences, and cultural power, ed. E. Seiter, H. Borchers, G. Kreutzner and E. Warth, 44-55. London: Routledge.

Hoorn, J.F. and E.A. Konijn. 2003. Perceiving and experiencing fictional characters: An integrative account. Japanese Psychological Research 45(4): 250-268.

Konijn, E.A. and J.F. Hoorn. 2005. Some like it bad: Testing a model for perceiving and experiencing fictional characters. Media Psychology 7(2): 107-44.

Kreutzner, G. and E. Warth. 1994. 'I was thirteen and my best friend got me hooked': An interview with two soap opera viewers. In Never-ending stories: American soap operas and the cultural production of meaning, ed. H. Borchers, G. Kreutzner and E. Warth, 164-194. Trier: Wissenschaftlicher Verlag Trier.

Larson, M.S. 1996. Sex roles and soap operas: What adolescents learn about single motherhood. Sex-Roles 35(1/2): 97-110.

Laverty, S.M. 2003. Hermeneutic phenomenology and phenomenology: A comparison of historical and methodological considerations. International Journal of Qualitative Methods 2(3): 1-29.

Liebes, T. and S. Livingstone. 1998. European soap operas: The diversification of a genre. European Journal of Communication 13(2): 147-180.

Livingstone, S. 1989. Interpretive viewers and structured programs: The implicit representation of soap opera characters. Communication Research 16(1): 2557.

Livingstone, S. 1990. Interpreting a television narrative: How different viewers see a story. Journal of Communication 40(1): 72-85.

Livingstone, S. 1998. Making sense of television: The psychology of audience interpretation, $2^{\text {nd }}$ edition. London: Routledge.

Livingstone, S. 1999. New media, new audiences? New Media and Society 1(1): 59-66. 
Lockyear, H. 2004. Multiculturalism in South African soap operas. Communicatio 30(1): 26-43.

Marx, H. 2008. South African soap opera as the other: The deconstruction of hegemonic gender identities in four South African soap operas. Communicatio 34(1): 80-94.

Nabi, R.L. and M. Krcmar. 2004. Conceptualising media enjoyment as attitude. Communication Theory 14(4): 288-310.

O'Guinn, T.C. and L.J. Shrum. 1997. The role of television in the construction of consumer reality. Journal of Consumer Research 23(4): 278-294.

Pitout, M. 1998. Die strukturele kenmerke van die televisie-seepopera: 'n Ondersoek na die populariteit van die seepoperagenre. Communicatio 24(1): 39-47.

QI. (2006). Project Platinum - Market research conducted on behalf of the SABC to evaluate the soap opera Isidingo. Corporate document.

Ratner, C. 2001. Analyzing cultural-psychological themes in narrative statements. Forum: Qualitative Social Research 2(3): 1-8.

Riegel, H. 1996. Soap operas and gossip. Journal of Popular Culture 29(4): 201-209.

Segrin, C. and R.L. Nabi, 2002. Does television viewing cultivate unrealistic expectations about marriage? Journal of Communication 52(2): 247-263.

Tager, M. 1997. Identification and interpretation: The Bold and the Beautiful and the urban black viewer in KwaZulu-Natal. Critical Arts: A South North Journal of Cultural \& Media Studies 11(1/2): 95-110.

Thompson, C.J. 1997. Interpreting consumers: A hermeneutical framework for deriving marketing insights from the texts of consumers' consumption stories. Journal of Marketing Research 34(4): 438-455.

Tulloch, J. 2000. Watching television audiences: Cultural theories and methods. New York: Arnold.

Warth, E. 1994. 'And that's my time': Soap operas and the temporal organization of women's everyday lives. In Never-ending stories: American soap operas and the cultural production of meaning, ed. H. Borchers, G. Kreutzner and E. Warth, 216-226. Trier: Wissenschaftlicher Verlag Trier.

Wyer, R.S. and R. Adaval. 2004. Pictures, words, and media influence: The interactive effects of verbal and nonverbal information on memory and judgments. In The 
psychology of entertainment media: Blurring the lines between entertainment and persuasion, ed. L.J. Shrum, 137-159. Mahwah, NJ: Lawrence Erlbaum. 